\title{
Inventory, Geographical Distribution of Caryedon Species in Burkina Faso, and Evaluation of Their Impact on Stored Groundnut
}

\author{
Issoufou Ouedraogo $^{{ }^{*}}$, Mbacke Sembene ${ }^{2}$, Dona Dakouo ${ }^{3}$ \\ ${ }^{1}$ INERA/Station de Farako-Bâ, Bobo-Dioulasso, Burkina Faso \\ ${ }^{2}$ Département de Biologie Animale, Université Cheick Anta Diop de Dakar, Dakar, Senegal \\ ${ }^{3}$ UFR-SVT, Université de Ouagadougou, Ouagadougou, Burkina Faso \\ Email: ${ }^{\star}$ yeguere@yahoo.com
}

How to cite this paper: Ouedraogo, I., Sembene, M. and Dakouo, D. (2017) Inventory, Geographical Distribution of $\mathrm{Ca}$ ryedon Species in Burkina Faso, and Evaluation of Their Impact on Stored Groundnut. Advances in Entomology, 5, 55-67. https://doi.org/10.4236/ae.2017.52005

Received: December 13, 2016

Accepted: February 7, 2017

Published: February 10, 2017

Copyright $\odot 2017$ by authors and Scientific Research Publishing Inc. This work is licensed under the Creative Commons Attribution International License (CC BY 4.0).

http://creativecommons.org/licenses/by/4.0/

\begin{abstract}
To understand the mechanism of infestation of stored groundnut in farming areas, studies on the inventory and geographical distribution of Caryedon species were carried out in the tree savannah and in producers' storage structures. The incidence of $C$. serratus in stored groundnut was evaluated. Inventory and geographical distribution of insects belonging to Caryedon genus was achieved through a sampling in the savannah and producers' granaries. The inventory and geographical distribution of insects was made throughout Burkina Faso whereas the evaluation of the perforations of groundnut pods was made in the western zone of the country. The results of the inventory showed the presence of two species belonging to Caryedon genus which are C. serratus and C. crampelii. These species are found on the agro-ecological zones of the country. The survival and maintenance of Caryedon species genus are ensured by the presence of plants belonging to various families such as Caesalpiniceae and Mimosaceae. The evaluation of the losses caused by C. serratus in producer's stored groundnut revealed that the pods perforation rate varied according to the locality. In Toussiana, the rate of perforated pods ranged from $53.72 \%$ to $100 \%$ in five months while in Karangasso Sembla, for the same conservation time, the rate was in the range from $2.8 \%$ to $35 \%$. However it is C. serratus which is responsible for the losses observed in the stored groundnut. Indeed, in the western area of Burkina Faso where more than 25\% of the production is realized, $70 \%$ of groundnut stocked without treatment is destroyed by this insect after only four months of storage.
\end{abstract}

\section{Keywords}

Groundnut, Inventory, Sahelian Zone, Caryedon sp., Burkina Faso 


\section{Introduction}

The genus Caryedon to which the serratus species belongs was already described under about several names [1]. The genus Caryedon contains species which is morphologically very similar and its presence is reported in all part parts of the word [2]. The genus Caryedon was reported by several authors in several tropical regions of Africa, Asia, Mexico and in Australia [2] [3] [4] [5] [6]. Recent phylogenic studies place beetles in the Chrysomelidae family and subfamily of Bruchidae [7] [8] [9]. This family is composed of 1700 species describes divided into 60 genus, subdivided into five subfamilies [2] [10]. In Burkina Faso, the presence of $C$. serratus was reported by several authors [1] [11]. The presence of this insect in stored groundnut can involve its total destruction within a few months. The importance of the losses caused by this insect pest during storage justifies the scientific research work which is devoted it [12] [13] [14]. However, in Burkina Faso where the production of groundnut is important with 325,000 tons of groundnuts hulls produced in 2014 [15], very little work exists on this important insect pest of stored groundnut [11]. However, the modes of infestation of stored groundnut are not well-known. This is the same about the origin of the beetles which infest stored groundnut in producer's zones. The aim of the present work is to make a geographical inventory and distribution of the insects of the genus Caryedon in the agro-ecological zones of the country and to evaluate the impact of this insect on the groundnut stocks in order to situate the level of losses due to these insects.

\section{Materials and Methods}

\subsection{Inventory and Geographical Distribution of Caryedon sp. in Burkina Faso}

Inventory and geographical distribution of insects of the genus Caryedon was carried out in the three agro-ecological areas of Burkina Faso during three consecutive years [16]. Each sampling zones was geo-referenced (Figure 1). In the Sahelien zone, the sampling was carried out in the locality of Dori. In the northern Sudanian zone, sampling related to the sites of Saria, Gonse, Boussé, Sapone, Boassa, Leo, Fada N'gourma, Tapoa, Gassan, Di, Solenzo, Dandé, Dédougou and Nouna. In the southern Sudanian zone, the collection of the samples was carried out on the sites of Vallée du Kou, Banfora, Yendéré, Farako-Bâ, Toussiana, Karangasso sembla, Darsalamy and Niangoloko.

The fruits of the wild host plants found in the different zones were collected. For the plants with pods, 30 fruits were collected on the host plants found in each area. Date and area of sampling were recorded.

Once in the laboratory, the fruits were isolated by plant species and locality in aerated bottles at room temperature until the emergence of adults.

\subsection{Inventory of Caryedon sp. in Stored Groundnut in Farming Areas}

On each sampled site and place where groundnuts are produced, the collection 


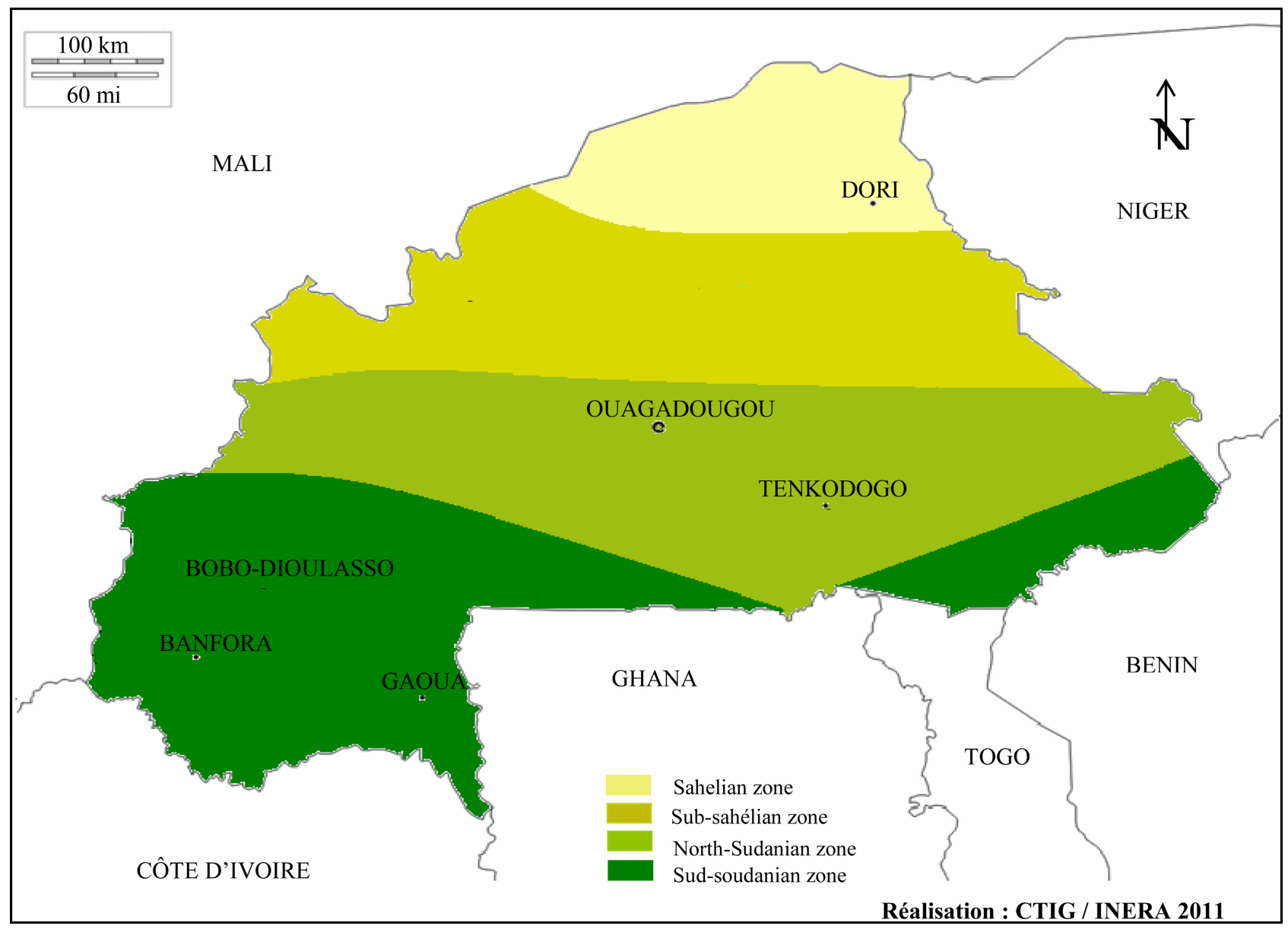

Figure 1. Inventory zones of insects of the genus Caryedon.

of groundnut was carried out in the producers' storage according to stocks availability. The sampling quantities per producer was $1 \mathrm{~kg}$ on average.

\subsection{Identification of the Collected Insects}

The samples of groundnut varieties (SH 470P; RMP12; RMP91; TS 32-1) collected in producer zones were isolated by locality in bottles and observed in the laboratory until the potential emergence of insects. The same procedure was followed for the fruits of the wild plants. At the emergence, the adult insects were identified by the male genitalia method according to Prevett's determination key (4) for the species of beetles of the genus Caryedon. The identification of plant species was made according to the Sahel trees and shrubs description [17]. Some plant species were identified by researchers from the forest production department of INERA.

\subsection{Incidence of $C$. serratus on Stored Groundnut at Groundnut Producers'}

The impact of $C$. serratus on groundnut storage was evaluated in the localities of Toussiana and Karangasso Sambla. The choice of these localities is justified by the importance of groundnut production and the strong pressure exerted by in- 
sects on groundnut stocks. Five producers were selected in each of the two localities and five kilograms of unshelled groundnut, untreated and non-infestedgroundnut was given to each producer. The varieties used are those cultivated in the area. Each month, samples were taken to track the level of infestation of groundnut stocks and identify the insects which are present. The samples were returned to the laboratory, the pods were observed to count those which are perforated and those which still contain larvae. To determine the rate of infested pods, the latter were shelled and observed to check those which really contain larvae. The parameters studied were:

- the rate of perforated pods $=(\mathrm{Nbr}$ of perforated pods/Nbr of total pods $) \times$ 100

- Insects species found in groundnut stocks

\subsection{Statistical Analysis of the Data}

The analysis of variance on observed parameters were carried out by the means of XLSTAT software version 6.1.9. When the analysis of variance reveals significant differences, the test of Fisher (LSD) was applied for the comparison of averages at the probability threshold set at 5\%. The formula of Abbott [18] was used to take into account natural mortality in the batches of groundnut.

\section{Results}

\subsection{Inventory and Geographical Distribution of Insects of the Genus Caryedon in Burkina Faso}

The sampling of fruits of plant species revealed 2172 adults which were compared with 1193 adults collected from the northern Sudanese zone. In total two species of the genus Caryedon namely $C$. serratus Olivier and Caryedon crampelii have been identified among the specimens which emerged.

The presence of species of the genus Caryedon was established on all the different zones where the samples were collected (Figure 1). The two species $C$. serratus and $C$. crampeli species were present in the sites of northern and southern Sudanese zones (Figure 2). As for the Sahelian zone, only C. serratus species was found. In the southern Sudanese zone, C. serratus was found on all the prospected sites showing that this species is well established in the area. As for the $C$. crampeli species, it was found on the pods of $P$. africana and $C$. sieberiana. Its presence seems to follow the distribution of its host plants because $C$. crampeli was found only on five of the 32 sites of this study.

\subsection{Identification of Insects in Groundnut Stocks}

Results (Table 1) show that several species of insects belonging to different orders have been observed in groundnut stocks collected in producer's environments. Among these species, C. serratus was found in the majority of samples, except for those coming from Saria, Boassa, Fada Ngourma and Farako-Bâ. As for the other species found, we can list Tribolium castaneum (Herbest), Oryzaephilus surinamensis (L.) and Plodia interpunctella (Hübner). Groundnut 


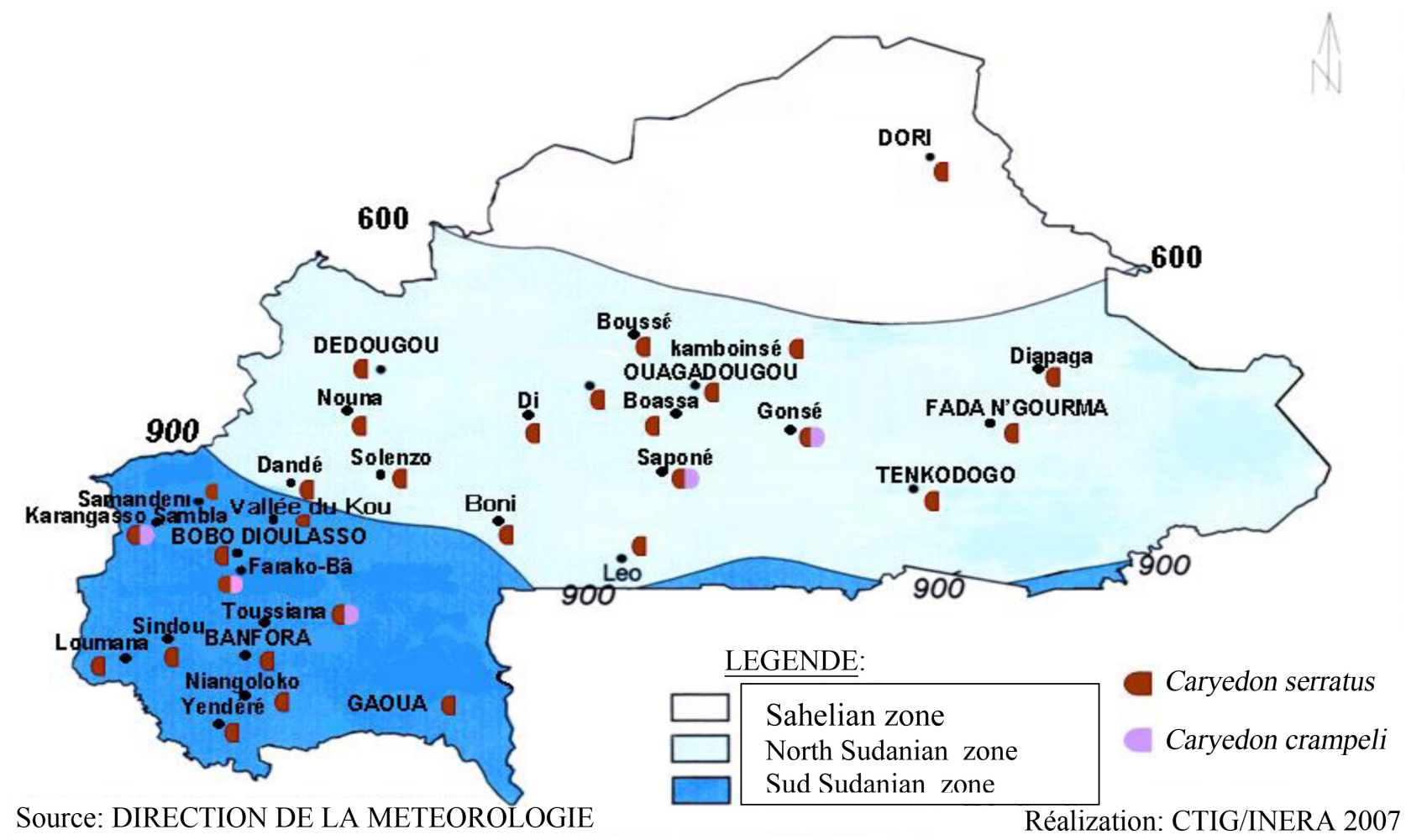

Figure 2. Map of the main species of Caryedon sp. inventoried in Burkina Faso.

Table 1. Main families of insects found in groundnut stocks in producers.

\begin{tabular}{cccc}
\hline Order & Family & Species/genus & Status \\
\hline \multirow{3}{*}{ Coleoptera } & Bruchidae & Caryedon serratus & I \\
& Tenebrionidae & Tribolium castaneum & II \\
& Sylvanidae & Oryzaephilus surinamensis & II \\
Lepidoptera & Phycitidae & Plodia interpunctella & II \\
\hline
\end{tabular}

during storage was infested by four families of insects namely Bruchidae, Tenebrionidae and Sylvanidae which belong to the order of Coleoptera. The fourth family found is Phycitidae which belongs to the order of Lepidoptera.

\subsection{Distribution of Host Plants of the Genus Caryedon sp. in Different Areas of Burkina Faso}

The main host plants of $C$. serratus are listed on Table 2. Fifteen plant species belonging to five botanical families that are Mimosaceae, Caesalpiniceae, Papilionaceae, Meliaceae and Fabaceae. Among each host plants family, five plant species belonging to the family of Caesalpiniaceae were listed, namely Bauhinia. rufescens, Cassia sieberiana, of Piliostigma reticulatum, Piliostigma. thonningii, and Tamarindus indica (Figure 3). All these plant species were collected in the northern and southern Sudanese zones except for $P$. thonningii that dominated in collected samples in the southern Sudanese zone. Two collected and identified species belong to the family of Fabaceae, namely Albizia lebbeck which was collected in the two zones and $S$. siamea found solely in the southern Sudanese 


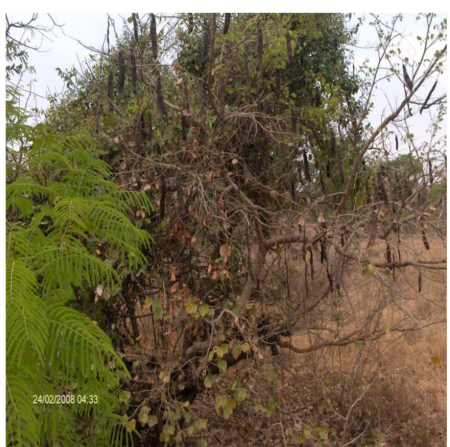

(a)

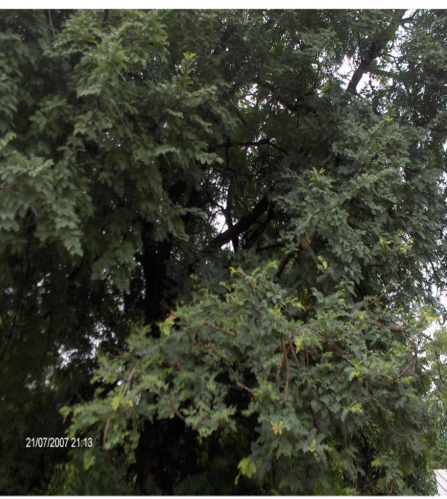

(c)

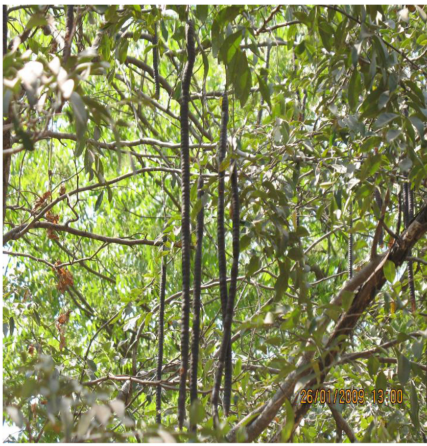

(b)

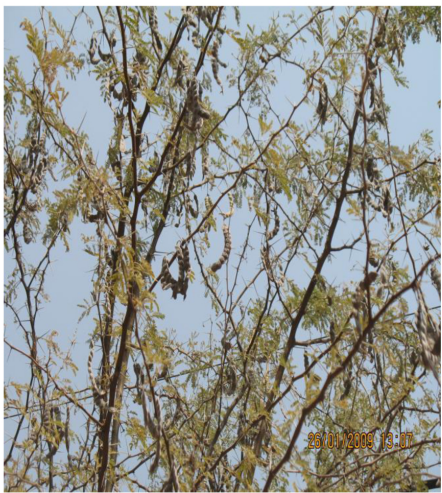

(d)

Figure 3. Some host plants of Caryedon serratus in Burkina Faso (Photo: Ouédraogo issoufou). (a) Piliostigma thonningii; (b) Acacia sieberiana; (c) Tamarindus indica; (d) Acacia nilotica var. adansonii.

Table 2. Main plants listed during inventory of Caryedon sp.

\begin{tabular}{|c|c|c|c|}
\hline Host plants & Family & $\begin{array}{c}\text { Northern } \\
\text { Sudanese } \\
\text { Zone }\end{array}$ & $\begin{array}{c}\text { Southern } \\
\text { Sudanese } \\
\text { Zone }\end{array}$ \\
\hline Bauhinia rufescens (Lam.) & Caesalpiniceae & + & + \\
\hline Cassia sieberiana (D.C) & Caesalpiniceae & + & + \\
\hline Piliostigma reticulatum (DC.) Hochst & Caesalpiniceae & + & + \\
\hline $\begin{array}{l}\text { Piliostigma thonningii (Schum.) } \\
\text { Miln-Redh }\end{array}$ & Caesalpiniceae & & + \\
\hline Tamarindus indica (L.) & Caesalpiniceae & + & + \\
\hline Albizia lebbeck (L.) Benth & Fabaceae & + & + \\
\hline Senna siamea (ex cassiasiamea) & Fabaceae & & + \\
\hline Daniella oliveri (R.) Hutch \& Dalz & Meliaceae & & + \\
\hline $\begin{array}{c}\text { Acacia nilotica (L.) Wildvar. } \\
\text { Adansonii (L.) }\end{array}$ & Mimosaceae & + & + \\
\hline Acacia sieberiana (D.C) & Mimosaceae & + & + \\
\hline Dichrostachys cinerea (L.) Wight et Arn. & Mimosaceae & + & + \\
\hline Prosopis juliflora (Sw.) DC., & Mimosaceae & + & + \\
\hline Faidherbia albida (Chev.) & Mimosaceae; & & + \\
\hline Prosopis africana (G. \& Perr.) & Mimosaceae; & + & + \\
\hline Arachis hypogaea (L.) & Papilionaceae & + & + \\
\hline
\end{tabular}

+ : Present in the zone. 
zone. In the family of Mimosaceae, six plant species were collected: Acacia nilotica var. adansonii (Figure 3), Cassia. Sieberiana (Figure 3), Dichrostachys cinerea, Prosopis juliflora (Figure 3), Prosopis africana and Faidherbia albida. In the other plant families, Arachis hypogea of the family of Papilionaceae and Daniella oliveri of the family of Meliaceae were the only plant species collected in their respective families.

\subsection{Influence of Host Plants on the Geographical Distribution of Caryedon sp.}

The fruits collected in the different geographical areas of the country and under observation allowed to obtain adults (Figure 4 and Figure 5). In the northern Sudanian zone, adult emergence rates of Caryedon were observed on five plants belonging to two plant families' species (Figure 4). Among the 1193 adults that emerged, in the fruits of $P$. reticulatum showed the most important rate of emergence (69.15\% emergence). $23.55 \%$ adults emerged from the pods of $T$. indica collected in the northern Sudanese zone, versus $5.28 \%$ of emergences of adults from the fruits of $B$. rufescens. As for the other plant species, the rates of emergences varied from $0 \%$ to $0.67 \%$ depending on the host plants.

In the southern Sudanese zone (Figure 4), the highest rate of emergence was observed from the pods of $P$. thonningii (59.34\% emergence) followed by the pods of $T$. indica (35.49\% emergence), C. sieberiana (4\%). As for the plant species $S$. siamea and $P$. africana, the rate of emergence of the adults of the genus Caryedon was respectively $0.59 \%$ and $0.55 \%$ (Figure 5).

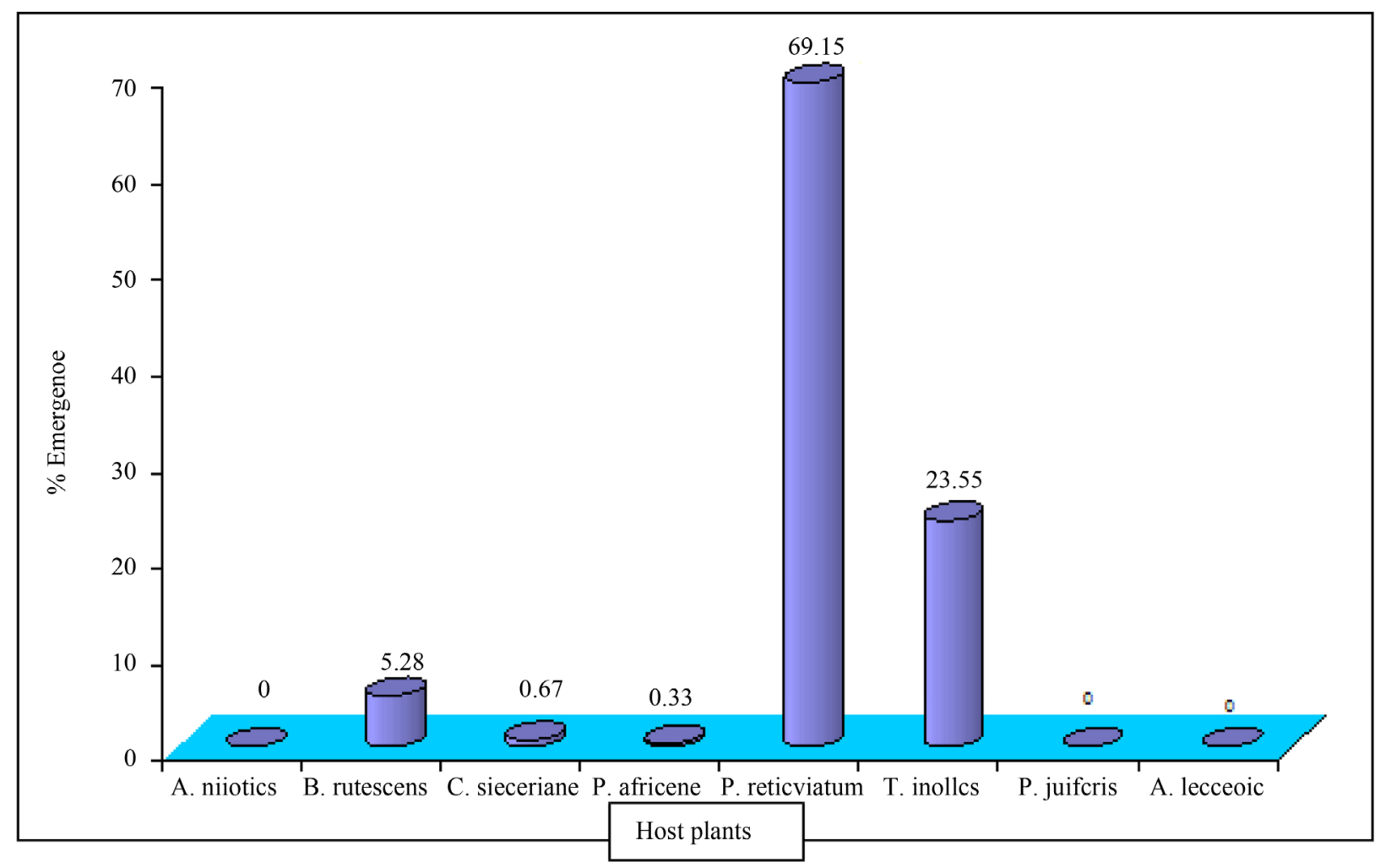

Figure 4. Percentage of emergence of the adults of Caryedon on different wild plants collected in the northern Sudanianzone. 


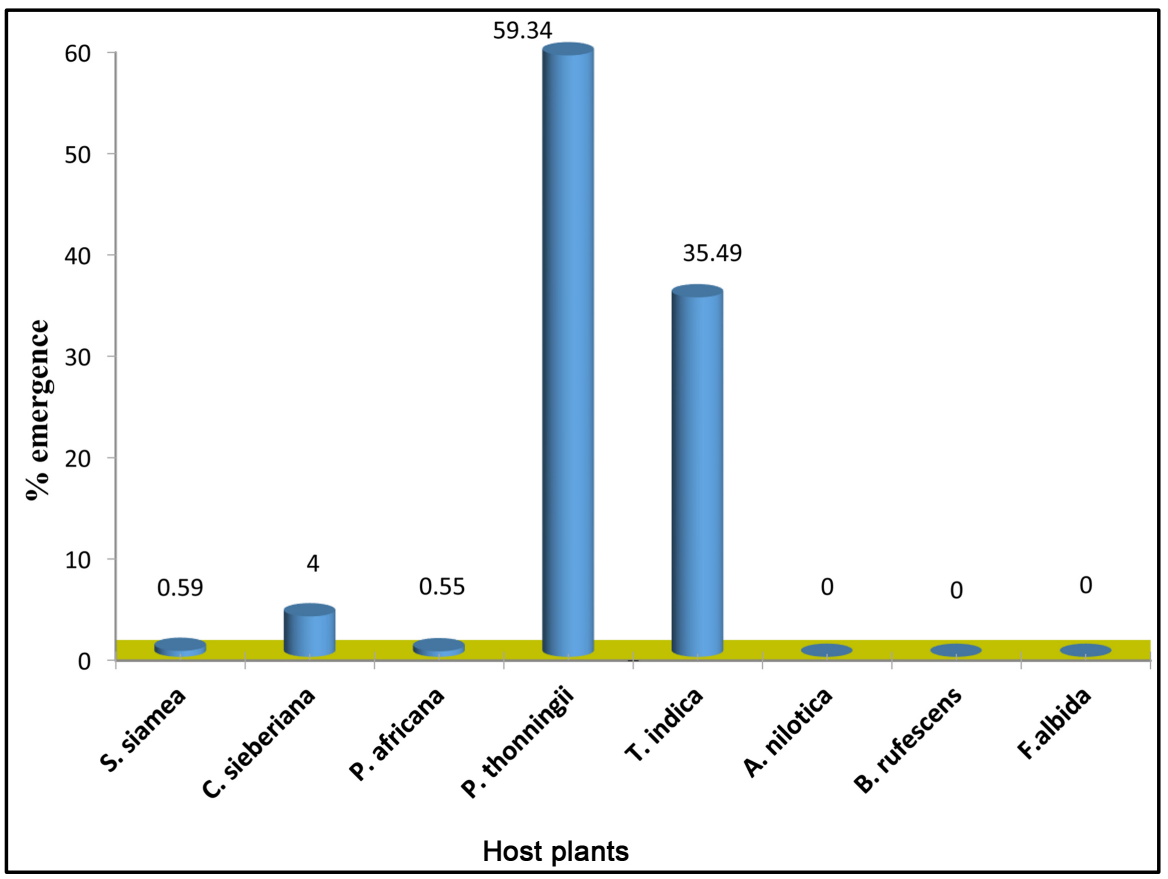

Figure 5. Percentage of emergence of the adults of Caryedon on different wild plants collected in the sudSudanian zone.

\subsection{Incidence of Insects of the Genus Caryedon on Groundnut Stocks in Farming Areas}

Analysis of the results (Figure 6) showed that the percentage of perforated pods was greater at Toussiana. Indeed, two months after the beginning of samplings, the average percentage of perforated pods was of $53.72 \%$. This rate moved to $81.18 \%$ at the third month of sampling to $89.78 \%$ at the fourth month. From the fifth month, all the groundnut pods independently of producers carried at least one opening.

In Karangasso Sambla (Figure 7), the analysis of results emphasized the same tendency as the one observed in Toussiana. In this locality, the average percentage of perforated pods increased progressively, moving from $0 \%$ at the first month to $2.8 \%$ at the second, $10.8 \%$ at the third, $21.40 \%$ at the fourth and $35 \%$ at the sixth month. In the two zones the rate of performed pods by insects varied significantly depending on the duration of storage.

\section{Discussion}

The inventory of Caryedon carried out in the different agro-ecological zones showed that only two species was identified and our results confirm the presence of two species of Caryedon distributed throughout the Burlkina Faso. These species were found in the whole of the agro-systems of Burkina Faso with a clear prevalence for $C$. serratus species. Its presence in all the prospected sites is explained by a homogeneous distribution of its host plants. In fact, on the faunistic inventory carried out, six host plants are well-distributed on the whole country allowing the development of the populations of $C$. serratus. Thus in the Sahelian 


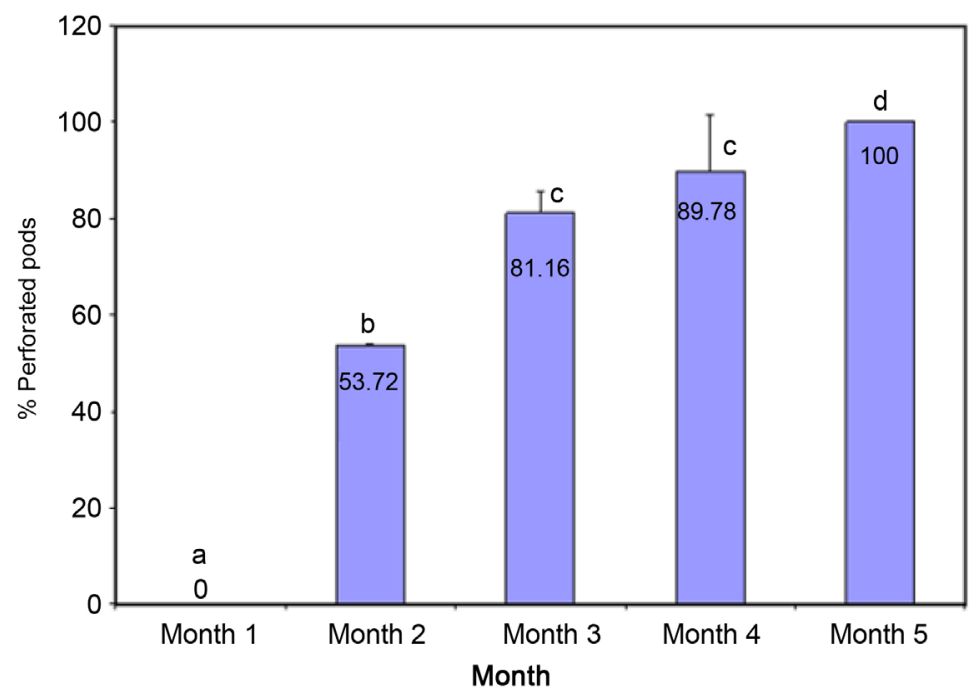

Figure 6. Average monthly evolution of perforated pods with producers of Toussiana ( $\pm \mathrm{ES})$.

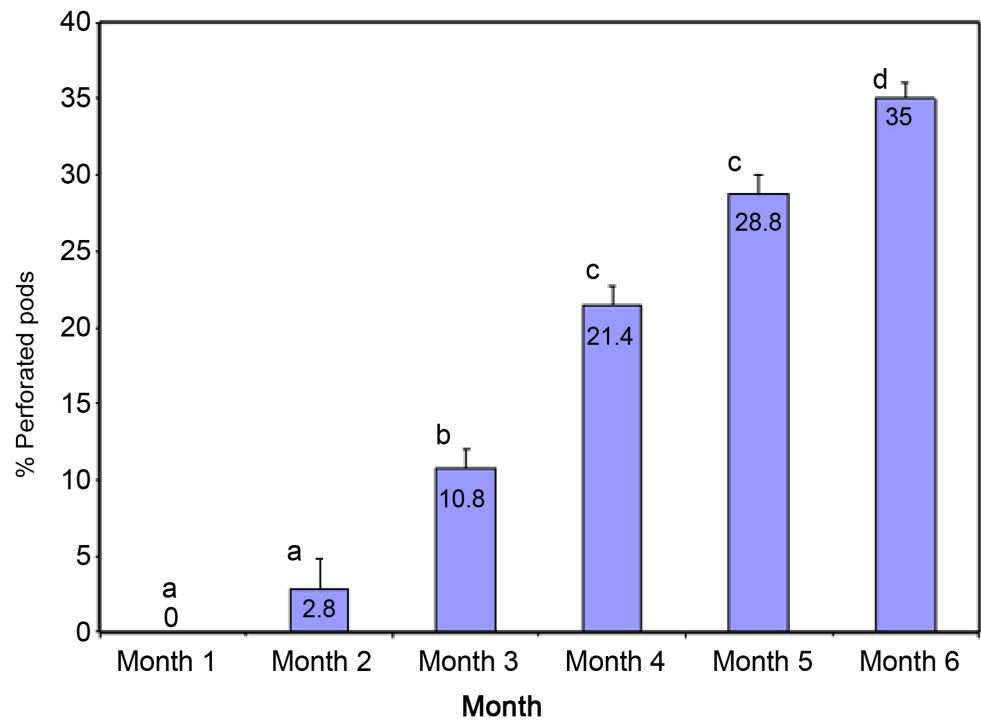

Figure 7. Average monthly evolution of perforated pods with producers of Karangasso Sambla ( \pm ES).

zone of Dori, C. serratus was found on B. rufescens, a perennial plant that can live and develop in arid regions where the pluviometry is bellow $600 \mathrm{~mm}$. This situation represents an adaptation of this plant species which was also found in wet zones as in Congo Brazaville [19]. The geographical distribution of C. serratus beetle is not related to climatic conditions but to the presence of host plants which are likely to allow its development and keeping alive. This explains why the species was indexed in several zones of the world [2] [7].

During groundnut storage, several groups of insects associated to this crop during were found that confirms the observations which report that groundnut is attacked by several groups of insects at the time of storage among which $C$. serratus, E. cautella, P. interpunctella and T. castaneum [20]. In some areas of 
Asia and Africa, Trogoderma granarium Eversts and Elasmolumus sordicus (Fabricus) were also found at the beginning of storage of groundnut [21]. Among the insects found in groundnut stocks, only the C. serratus species is able to attack the intact groundnut pods [9]. Thus no matter the zone considered, the C. serratus beetle seems to be the most harmful insect of groundnut stocks [22] [23] [24]. In the northern Sudanese zone where the density and diversity of host plants is relatively important, $C$. serratus is predominant confirming the observations of several authors [2] [7].

The low number of $C$. crampelli species is related to the reduced number of its host plants whose geographical distribution is not always homogeneous. It is the case of $P$. africana main host plant of $C$. crampelii. The important use of the pods of this plant in animal feed led to the scarcity of its pods and thus of $C$. crampelii in some areas. The identified species of Caryedon differ from those identified by other authors [25]. In fact these authors reported the presence of Caryedon nongoniermai (ex Caryedon sahelicus Decelle), species which was collected in 1967 on Acacia tomentosa in the area of Ouagadougou. The second species identified by these authors, Caryedon furcatus (ex C. mauritanicus Decelle), the specimens were collected in 1969 in the area of Fada Ngourma. The degradation of the ecology of insects and the destruction of their host plants can explain this situation.

The plants play an important role in the development of the beetle like the species Caryedon. Indeed, the presence of $P$. thonningii and $T$. indica constitute sources of infestation in groundnut in Congo and Senegal [13] [26].

The host plants which ensure the survival and distribution of bruchidae in Burkina Faso are favorable to the evolution of these insects. The absence of secondary substances in these plants unfavorable to the evolution of the larvae of these insects that explain the preference of these plants by these insects [27].

As for groundnut, very little research work on the losses caused by $C$. serratus in farming areas on this leguminous plant is available apart from those reported in Congo Brazaville [26]. In Burkina Faso, the evaluation of farmers' losses has permitted to quantify the damage caused by this insect. Thus in the western zone C. serratus causes important perforations on groundnut pods during conservation. The presence of an important population of beetle in old infested groundnut stocks, just as the presence of host plants which support their development and keeping explains the level of damage observed.

In fact, in Congo Brazaville, $P$. thonninginis one of the sources of infestation of groundnut stocks [26]; while in Senegal 2\% of the adults of C. Serratus which infest groundnut originate in the wild host plants [10]. This last point seems the most important in the infestations of groundnut stocks. Indeed, the pods of $T$. indica which carry eggs and sometimes the larvae of $C$. serratus are gathered, preserved and used gradually according to needs (culinary, commercial or medical). It is the same case for the pods of $P$. thonningii and $P$. reticulatum which are gathered and preserved for feeding animals during the dry season. Thus parts of the insects which infest groundnut stocks come from these host plants. 


\section{Conclusion}

The inventory work carried out in the agro-ecological zones of the country has permitted to identify the presence of two species of Caryedon which are C. serratus and C. crampelii. Studies on the geographical distribution of these species indicate that they are present in various agricultural zones of Burkina Faso. $C$. serratus is the widely spread species; it was found in all the agro-ecological zones of the country. In the western zone of Burkina Faso, the checking of groundnut stocks showed that only $C$. serratus infests groundnut stocks. The laying and nutrition activities of the larvae of $C$. serratus in groundnut stocks are at the basis of the perforation of groundnut pods which can reach $70 \%$ without any protection methods. The importance of the damage observed in groundnut stocks is explained by the presence of old stocks of groundnut "infested with beetles" but also by the gathering and conservation of some wild fruits such as the pods of $T$. indica and $P$. thonningii which generally are infested by $C$. serratus and which constitute sources of infestation of groundnut stocks. The results showed us the mode of infestation of groundnut stocks in the rural areas of Burkina Faso and this study can foster ways and means for the reduction of the perforations of groundnut pods related to the presence of $C$. serratus.

\section{Acknowledgements}

This work was achieved thanks to the financial support of the International Foundation for Science (IFS).

\section{Competing Interest}

Authors have declared that no competing interests exist.

\section{References}

[1] Robert, P. (1984) Contribution à l'étude de l'écologie de la bruche de l'arachide: Caryedon serratus Ol. (Coleoptera, Bruchidae), sur ses différentes plantes hôtes. Thèse de 3e cycle, Université François Rabelais de Tours, France, 122 p.

[2] Johnson, C.D., Southgate, B.J. and Delobel, A. (2004) A Revision of the Caryedontini (Coleoptera: Bruchidae: Pachymerinae) of Africa and the Middle East. Memoirs of the American Entomological Society, 44, 126 p.

[3] Delobel, A., Delobel, H., Tran, M., Sembene, M. and Han, H.S. (1995) Observations sur les relations trophiques entre les bruches du genre Caryedon (Coleoptère, Bruchidae) et leurs plantes hôtes sauvages au Sénégal. Bulletin de l'Institut Fondamental d'Afrique Noire, Cheick AntaDiop, 48, 79-88.

[4] Prevett, P.F. (1965) The Genus Caryedon in Northern Nigeria, with Descriptions of Six New Species (Col. Bruchidae). Annales de la Société Entomologique de France (N.S), 1, 523-547.

[5] Johnson, C.D. and Kingsolver, J.M. (1981) Checlist of the Bruchidaea (Coleoptera) of Canada, United States, Mexico, Central America and the West Indies. Coleopterists Bulletin, 35, 409-422.

[6] Romero, J. and Johnson, C.D. (2002) Cassia moschata H.B.K., New Host for Caryedon serratus (Olivier) in the New World (Coleoptera: Bruchidae: Pachymerinae). The Coleopterists Bulletin, 56, 95-96. 
https://doi.org/10.1649/0010-065X(2002)056[0095:SN]2.0.CO;2

[7] Johnson, C.D. and Romero-Nápoles. J.J. (2004) A Review of Evolution of Oviposition Guilds in the Bruchidae (Coleoptera). Revista Brasileira de Entomologia, 48, 401-408. https://doi.org/10.1590/S0085-56262004000300017

[8] Cunnigham, D.C. and Walsh, K.B. (2002) Establishment of the Peanut Bruchid (Caryedon serratus) in Australia and Two New Host Species, Cassia brewsteri and C. tomentella. Australian Journal of Experimental Agriculture, 42, 57-63. https://doi.org/10.1071/EA00182

[9] Sembene, M., Kebe, K., Delobel, A. and Rasplus, J.Y. (2010) Phylogenetic Information Reveals the Peculiarity of Caryedon serratus (Coleoptera, Chrysomelidae, Bruchinae) Feeding on Cassia sieberiana DC (Caesalpinioideae). African Journal of Biotechnology, 9, 1470-1480. https://doi.org/10.5897/AJB09.1286

[10] Southgate, B.J. (19790 Biology of the Bruchidae. Annual Review of Entomology, 24, 449-473. https://doi.org/10.1146/annurev.en.24.010179.002313

[11] Lafleur, G. (1994) Effet des pyréthrinoïdes, du neem, de la terre diatomée et de l'enfumage sur la bruche de l'Arachide. Sahel PV Information, 66, 9-14.

[12] Sembene, M. (2000) Variabilité de l'espaceur transcrit (ITS1) de l'ADN ribosomique et polymorphisme des locus microsatellites chez la bruche Caryedon serratus (Olivier): Différenciation en races d'hôtes et infestation de l'arachide au Sénégal. Thèse de Doctorat d'Etat es sciences, Université Cheick AntaDiop de Dakar, Dakar, $128 \mathrm{p}$.

[13] Sembène, M., Ndiaye, A., Doumma, A., Diome, T., Ndong, A., Kébé, K., Thiaw, C., Gueye, S., Sanon, A., Kétoh, G.K. and Delobel, A. (2011) Oviposition Preference and Levels Adaptation of Caryedon serratus Olivier (Coleoptera, Bruchidae) Hosts plant Strain to Groundnut (Arachis hypogaea, Fabaceae). South Asian Journal EXperimental Biology, 1, 48-55.

[14] Diome, T., Ndong, A., Kebe, K., Thiaw, C., Ndiaye, A., Doumma, A., Sanon, A., Ketoh, G. and Sembene, M. (2013) Effect of Agro-Ecological Zones and Contiguous Basin Crops of Groundnut (Arcahis hypogaea) on the Structuring and Genetic Diversity of Caryedonserratus (Coleoptera: Chrysomelidae, Bruchinae) in the SubRegion of West Africa. Journal of Asia-Pacific Entomology, 16, 209-217. https://doi.org/10.1016/j.aspen.2013.01.004

[15] Ministere Agriculture, Des Amenagements et Hydraulique (2016) Résultats définitifs de la campagne agricole 2015/2016 et perspectives de la situation alimentaire et nutritionnelle. $75 \mathrm{p}$.

[16] Sivakumar, M.V.K. and Gnoumou, F. (1987) Agroclimatologie de l'Afrique de l'ouest: Le Burkina Faso. Vol. 23, ICRISAT, Patancheru, 61 p.

[17] Von Maydell, J. (1983) Arbres et Arbustes du Sahel, leurs caractéristiques et leurs utilisations. Publié par GTZ, Hambourg, 310 p.

[18] Abbott, W.W. (1925) A Method for Computing the Effectiveness of an Insecticide. Journal of Economic Entomology, 18, 265-267.

https://doi.org/10.1093/jee/18.2.265a

[19] Delobel, A. (1989) Influence des gousses d'arachide (Arachishypogea L.) et de l'alimentation imaginale sur l'ovogenèse, l'accouplement et la ponte chez la bruche Caryedon serratus. Entomologiaexperimentalis et applicata, 52, 281-289. https://doi.org/10.1111/j.1570-7458.1989.tb01278.x

[20] Singh, F. and Oswalt, D.L. (1992) Major Pests of Groundnut. Skill Development Serie, Vol. 7, ICRISAT, Patancheru, 37 p.

[21] Dick, K.M. (1987) Pest Management in Stored Groundnut. Information Bulletin, 
Vol. 3, ICRISAT, Patancheru.

[22] Alzouma, I. (1995) Connaissance et Contrôle des coléoptères Bruchidae ravageurs des. légumineuses alimentaires au Sahel. Sahel IPM Nº́1 février, 2-16.

[23] Delobel, A. (2008) Les bruches. Insectes, 150, 1-4.

[24] Ouedraogo, I. (2011) Biologie et écologie de Caryedon serratus Olivier (Coleoptera: Chrysomelidae) dans un écosystème arachidier de L'ouest du Burkina Faso. Thèse de doctorat unique, Université de Ouagadougou, Burkina Faso, 120 p.

[25] Anton, K.W. and Delobel, A. (2004) Description of Five New Species in the Genus Caryedon Schoenherr, with a Taxonomical Note on C. angeri (SEMENOV) (Coleoptera: Bruchidae: Pachymerinae). Genus, 15, 65-90.

[26] Matokot, L., Mapangou-Divassa, S. and Delobel, A. (1987) Evolution des populations de Caryedon serratus (Ol.) (Coleoptera: Bruchidae) dans les stocks d'arachide au Congo. L'Agronomie Tropicale, 42, 69-74.

[27] Kergoat, G.J., Delobel, A., Fediere, G., le Rü, B. and Silvain, J.-F. (2005) Both Host-Plant Phylogeny and Chemistry Have Shaped the African Seed-Beetle Radiation. Molecular Phylogenetics and Evolution, 35, 602-611.

https://doi.org/10.1016/j.ympev.2004.12.024

Submit or recommend next manuscript to SCIRP and we will provide best service for you:

Accepting pre-submission inquiries through Email, Facebook, LinkedIn, Twitter, etc. A wide selection of journals (inclusive of 9 subjects, more than 200 journals) Providing 24-hour high-quality service User-friendly online submission system Fair and swift peer-review system Efficient typesetting and proofreading procedure Display of the result of downloads and visits, as well as the number of cited articles Maximum dissemination of your research work

Submit your manuscript at: http://papersubmission.scirp.org/

Or contact ae@scirp.org 